\title{
Use of rest areas by passenger car drivers on fast road network in Poland
}

\author{
Malwina Spławińska, ${ }^{1, *}$ \\ ${ }^{1}$ Cracow University of Technology, Faculty of Civil Engineering, Warszawska Street 24, 31-155 Cracow, Poland
}

\begin{abstract}
An integral part of a well-functioning network of national roads are Rest Areas (RA). They are crucial for road safety, provided that they are properly arranged and designed (not too long distance between them and enough number of parking spaces). They allow the drivers to safely stop and rest (use the toilet, use the telephone, eat a meal, sleep, etc.). However, in Europe, there is a shortage of parking spaces. In Poland, the situation is additionally complicated due to the lack of the current methodology for RA planning and design. There are also no indications for which traffic conditions a calculation should be made and measurements should be performed. The objectives of this study were to determine the use of rest areas by passenger car drivers, including in particular the determination of the percentage of vehicles entering the given RA and determination of the appropriate time interval for parking demand data collection. It was found that use of RA depend of its individual facilities and direction of movement (varied from $2.1 \%$ to $19.3 \%$ of the main-line traffic) and it's the biggest on Friday from 12:00 to 18:00. This study was conducted on four RA located in central region of Poland.
\end{abstract}

\section{Introduction}

Thanks to the National Road Construction Program for years 2011-2015, which was a continuation of the National Road Construction Program for years 20082012, from November 2007 to the end of 2016 in Poland $975 \mathrm{~km}$ of motorways and $1274 \mathrm{~km}$ of expressways were built [1]. National Road Construction Program for years 2014-2023 assumes the further development of the fast road network (increasing the density of motorways and expressways from $8.7 \mathrm{~km} / 1000 \mathrm{~km} 2$ to $17.5 \mathrm{~km} / 1000$ $\mathrm{km} 2$ ). An integral part of a well-functioning, consistent network of national roads are Rest Areas (RA). They are crucial for road safety, provided that they are properly arranged and designed (not too long distance between them and enough number of parking spaces). They allow the drivers to safely stop and rest (use the toilet, use the telephone, eat a meal, sleep, etc.). As indicated by national studies, driver fatigue is the cause of up to $20 \%$ of road accidents on the main road network and motorways [2]. In the years $2003-2007$, on motorways, such accidents accounted for $13.2 \%$ of all accidents and $13.5 \%$ of total casualties on national roads (more than four times higher share than on roads of other classes). It should be noted that passenger car drivers were responsible for $72.4 \%$ of accidents (truck drivers for $26.5 \%$ ). Moreover, according to [3], the percent of drivers who caused an accident as a result of falling asleep on motorways in 2016 amounts to about 15\% (this level has remained more or less stable since 2009), while on other roads it is about $2 \%$ (the number of accidents on motorways and other roads respectively was assumed as $100 \%$ ).

The aim of the article is the analysis of the use of rest areas by passenger car drivers, including in particular the determination of the percentage of vehicles entering the given RA taking into account its location and equipment, as well as the determination of the appropriate time interval for parking demand data collection. This information will allow for creating a theoretical and empirical basis enabling the increase in the quality and reliability of determining parking demand and, as a consequence, improvement of road safety.

\section{Literature review}

A study conducted in 1998 by Taylor and Sung investigated that the probability of a nighttime, singlevehicle truck accident increases rapidly when distances between rest areas increase beyond $50 \mathrm{~km}$ (according to hazard function). In turn, Banerjee et al. [4] showed the relationship between fatigue-related collisions and rest area location (fatigue-related collisions increasing approximately $50 \mathrm{~km}$ after rest areas) and the negative binomial regression models prepare by Michigan Department of Transportation [5] shown that RSA reduces fatigue-related crashes up to a $30 \mathrm{~km}$ radius in each direction (by 3.37 crashes per year). However, both in Europe and the U.S., there is a shortage of parking spaces, in particular in the group of heavy goods vehicles. The research carried out in 2013 by the Federal Ministry of Transport (BMVI [6]) proves the scale of the problem; it showed a shortage of around 11.000 truck 
parking spaces on German motorways. This means that for over $15 \%$ of vehicles, there is not enough legally designated parking space available. Considering that, due to poor parking management, even when there is an access to free spaces, a significant proportion of drivers park in an illegal manner [7], road safety can be reduced by disorderly parking trucks (on entry/exit slip roads, in area around petrol station, in road ways or on passenger car parking places). In Poland, the situation is additionally complicated due to the lack of the current methodology for RA planning and design. There are also no indications for which traffic conditions a calculation should be made and measurements should be performed. In foreign literature, two approaches can be found, i.e. the analysis is carried out either in relation to baseline rate of use of the RA for the peak daytime period or baseline rate use for the 24 hour period (in relation to AADT). It also shows that parking space demand depends on extrinsic parameters, which are in connection with the position and environment of RA (such as distance to intl. border, distance to large city, distance to the next interchange, distance from the previous rest area, daily traffic on major road) as well as intrinsic parameters, which are connected with architecture and usage of the RA (such as size, type of service, attached petrol station, welcome center, operation of a weighing station) [8-11].

In line with the recommendations in force in different countries, the maximum distance between rest areas should be from 15 to $100 \mathrm{~km}$, according to Table 1 (in line with the regulation [12], the minimum distance between RAs on motorways is $15 \mathrm{~km}$ ). Furthermore, according to [13], opportunities to stop should be provided at intervals of approximately half an hour (motorist should stop and rest at least 15 minutes every two hours). In Poland, three categories of RAs are distinguished, depending on their function, ie: RA I having a leisure function (with parking spaces, maneuvering area, rest and sanitary facilities as well as lighting), RA II having a rest and service function (with the same facilities as RA I and a petrol station, vehicle service stations, gastronomic and commercial facilities, tourist information points), RA III having a leisure and service function (with the same facilities as RA II and accommodation facilities). The recommended distance between consecutive RAs (RA I - RA II - RA I - RA III - RA I) is $20 \mathrm{~km}$. Taking into account the results regarding the impact of the RA location on the number of accidents described above, this spacing may be considered favorable. This is also confirmed by the results of research conducted in Korea, where in 2011 133 supplemental rest areas were installed and operated on the motorway system (KoEX) with an approximate $15-\mathrm{km}$ spacing between regular rest areas, and which resulted in a reduction in the number of crashes caused by drowsy driving from $22 \%$ in 2009 to $19 \%$ in 2012 [14]. Furthermore, from 2013 to 2014, the total number of crashes increased from 3231 to 3583, but in places where the KoEX installed the supplemental rest areas, there was a $14 \%$ reduction in the number of crashes caused by drowsy driving.
Table 1. Distance between rest area by country (source: own study based on [14]).

\begin{tabular}{|c|c|c|}
\hline Country & Type & Spacing Standard [km] \\
\hline \multirow{2}{*}{ Poland } & Rest Area I & $\begin{array}{c}40 \text { alternately with RA II } \\
\text { and RA III }\end{array}$ \\
\cline { 2 - 3 } & Rest Area II & $\begin{array}{c}40 \text { or 80 (in case of } \\
\text { occurrence of RA III } \\
\text { between them) }\end{array}$ \\
\cline { 2 - 3 } & Rest Area III & 80 \\
\hline \multirow{2}{*}{ U.S. } & Rest Area & 100 (real 50 km) \\
\hline \multirow{2}{*}{ Japan } & Service Area & 50 \\
\cline { 2 - 3 } & Parking Area & 15 \\
\hline U.K. & Service Area & 45 \\
\hline Korea & Rest Area & recommended 25 (real 42) \\
\hline
\end{tabular}

The basic parameter informing about the use of RA is main-line traffic entering rest areas $(\mathrm{P})$. This value can be determined either in relation to the total number of vehicles or to the individual groups of vehicles. Table 2 shows the typical values assumed in Poland and the U.S. (in the case of different values specified for individual groups of vehicles, the values referring to passenger cars are given). In addition, the table shows the period that should be assumed as meaningful in the planning and design of rest area facilities (peak parking demand). It should be noted that this period only partly overlaps with the hours in which the largest parking demand is observed. According to [10], higher parking demand in RA occurs from 12:00 am to 2:00 pm and 3:00 pm to 5:00 pm (it is higher on weekends than weekdays) and it strongly correlates with vehicular volume on major road (Pearson Correlation $>0.9$ ). It has also been shown that although not all vehicles stop at RA (some of travelers have a quick break or refuel the car), this has no effect on the parking capacity provided in RA. According to [8], the highest level of parking space occupation is between 8:00 - 9:00 and around 14:00 (the lowest is around midday).

Table 2. Main-line traffic entering rest areas and period considered in the planning and design in the U.S. and Poland.

\begin{tabular}{|c|c|c|}
\hline Country & $\begin{array}{c}\text { Main-line traffic entering } \\
\text { rest areas }\end{array}$ & $\begin{array}{l}\text { Design Hourly } \\
\text { Volume }\end{array}$ \\
\hline Poland & $15 \%$ & $\begin{array}{c}\text { afternoon hours } \\
(12: 00-13: 00 \text { or } \\
13: 00-14: 00) \\
\end{array}$ \\
\hline U.S. [9] & $9 \%$ & $\begin{array}{l}\text { 30th peak hour of } \\
\text { the year }\end{array}$ \\
\hline U.S. [11] & $\begin{array}{c}12 \%-15 \% \text { (welcome centers) } \\
8 \%-13 \% \text { (along recreational } \\
\text { routes) } \\
5.5 \%-9 \% \text { (broader use) }\end{array}$ & $\begin{array}{l}\text { 30th peak hour of } \\
\text { the year }\end{array}$ \\
\hline
\end{tabular}




\begin{tabular}{|c|c|c|}
\hline $\begin{array}{c}\text { U.S. [15, } \\
16]\end{array}$ & $\begin{array}{c}16 \% \text { (interstate motorways) } \\
25 \% \text { (rural arterials) }\end{array}$ & midday \\
\hline
\end{tabular}

\section{Data Collection}

Due to the impact of the RA location on its use, demonstrated in earlier works, $17 \mathrm{~km}$ of an A2 motorway section, homogenous in terms of traffic and lying beyond the influence of large metropolitan areas and border crossings, were dedicated to analysis. Along its length, two RAs are located in the two directions of traffic. The scope of individual RA facilities is presented in Table 3 (additionally all RA have fencing, lighting and toilets). It should be noted that on the analyzed A2 motorway section, the recommended RA distribution was modified, namely to RA I, every $40 \mathrm{~km}$ alternately with RA II or III, RA I was added at the halfway distance keeping the RA II/III distribution, according to Figure 1, which may affect the results. The analysis was performed based on data from the toll stations (traffic on main road) and from own measurements (passenger cars driving down to the RA). Traffic data were collected from each rest area site from 16.09.2016 (Friday) till 20.09.2016 (Tuesday) and has been aggregated to hourly volumes of passenger cars for each direction respectively.

Table 3. Information on the safety and facilities of parking spaces (A2 motorway section - KOŁO-DABIE).

\begin{tabular}{|c|c|c|c|c|c|c|}
\hline & & v & 苞 & 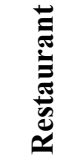 & 莡 & 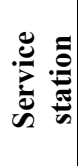 \\
\hline $\begin{array}{l}\text { RA III } \\
\text { Police }\end{array}$ & Berlin & Yes & Yes & Yes & Yes & Yes \\
\hline RA II Łęka & Warsaw & Yes & Yes & Yes & Yes & Yes \\
\hline $\begin{array}{c}\text { RA I } \\
\text { Cichmiana }\end{array}$ & Warsaw & No & No & No & No & No \\
\hline $\begin{array}{c}\text { RA I } \\
\text { Sobótka }\end{array}$ & Berlin & No & No & No & No & No \\
\hline
\end{tabular}

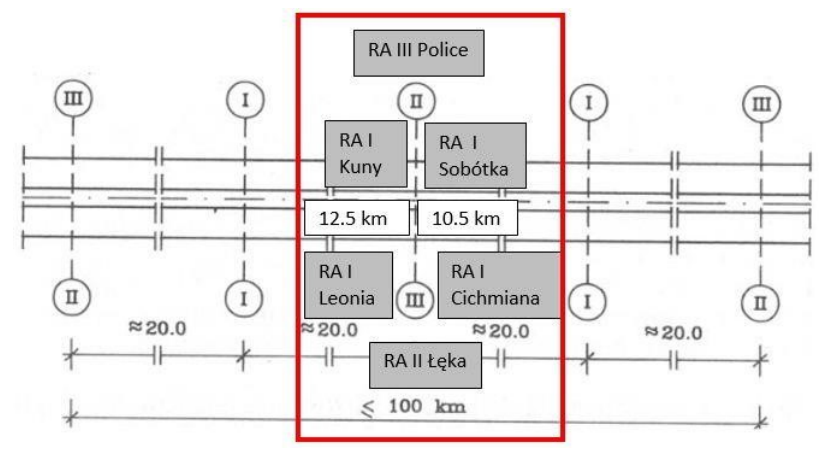

Fig. 1. Diagram of the arrangement of various types of RAs along the road, in accordance with WPD-1 (Road Design Guidelines).

\section{Traffic use of rest area}

Analyzes concerning the use of RAs by passenger car drivers consisted in determining the percentage share of vehicles driving down to a given RA in the number of vehicles in the cross-section of the road $(\mathrm{P})$. The coefficient $\mathrm{P}$ was determined in three variants, as follows:

- the number of vehicles entering the rest area divided by main-line traffic every hour $-\mathrm{P}_{\mathrm{h}}[\%]$,

- the number of vehicles entering the rest area divided by main-line traffic in one day $-\mathrm{P}_{24 \mathrm{~h}}[\%]$,

- the maximum number of vehicles entering the rest area divided by maximum main-line traffic (in an hour) $\mathrm{P}_{\max }[\%]$ (in the case of main-line traffic, the highest value was obtained for Friday between 17:00 and 18:00).

The obtained results are presented in Table 4 (in the case of $\mathrm{P}_{\mathrm{h}}$, the highest volume obtained on a given day of measurement was given). In the case of $\mathrm{P}_{\max }$, additionally, an hour was given in which the highest number of vehicles driving down to the RA was recorded (each time it was Friday).

Table 4. Percentage of vehicles in the road cross-section that stop at RA [\%].

\begin{tabular}{|c|c|c|c|c|c|c|}
\hline & & 16.09 & 17.09 & 18.09 & 19.09 & 20.09 \\
\hline \multirow{3}{*}{$\begin{array}{l}\text { RA III } \\
\text { Police }\end{array}$} & $\mathrm{P}_{\mathrm{h}}$ & 16.6 & 16.5 & 16.8 & 17.6 & 17.1 \\
\hline & $\mathrm{P}_{24 \mathrm{~h}}$ & 11.3 & 13.2 & 13.6 & 10.9 & 12.2 \\
\hline & $\mathrm{P}_{\max }$ & \multicolumn{5}{|c|}{$12.9(14: 00-15: 00)$} \\
\hline \multirow{3}{*}{$\begin{array}{c}\text { RA I } \\
\text { Sobótka }\end{array}$} & $\mathrm{P}_{\mathrm{h}}$ & 3.4 & 1.5 & 2.9 & 2.9 & 4.2 \\
\hline & $\mathrm{P}_{24 \mathrm{~h}}$ & 1.9 & 2.0 & 2.1 & 1.9 & 2.2 \\
\hline & $\mathrm{P}_{\max }$ & \multicolumn{5}{|c|}{$2.1(12: 00-13: 00)$} \\
\hline \multirow{3}{*}{$\begin{array}{l}\text { RA II } \\
\text { Łęka }\end{array}$} & $\mathrm{P}_{\mathrm{h}}$ & 19.3 & 20.0 & 16.8 & 13.6 & 23.6 \\
\hline & $\mathrm{P}_{24 \mathrm{~h}}$ & 17.3 & 17.5 & 16.5 & 14.0 & 16.1 \\
\hline & $\mathrm{P}_{\max }$ & \multicolumn{5}{|c|}{$19.3(16: 00-17: 00)$} \\
\hline \multirow{3}{*}{$\begin{array}{c}\text { RA I } \\
\text { Cichmia } \\
\text { na }\end{array}$} & $\mathrm{P}_{\mathrm{h}}$ & 3.2 & 3.8 & 3.8 & 3.7 & 3.5 \\
\hline & $\mathrm{P}_{24 h}$ & 2.1 & 2.3 & 2.3 & 2.5 & 2.3 \\
\hline & $\mathrm{P}_{\max }$ & \multicolumn{5}{|c|}{$3.2(17: 00-18: 00)$} \\
\hline
\end{tabular}

It can be noticed that, due to the shift of the peak time of RA use in relation to the traffic peak in the road cross-section, the highest values were obtained for $\mathrm{P}_{\mathrm{h}}$. In case of $\mathrm{P}_{24 \mathrm{~h}}$, similar values were obtained within the analyzed RA and similar to $\mathrm{P}_{\max }$, but only in the direction of Berlin. In addition, each time $\left(\mathrm{P}_{\max }\right.$ and 
average of $\mathrm{P}_{\mathrm{h}}$ and $\mathrm{P}_{24 h}$ ) in RA categories I and II or III, higher values were obtained for the Warsaw direction than Berlin direction. A similar dependence was also obtained for the next A2 motorway section lying in the zone of influence of Warsaw (in the direction of Warsaw, the maximum number of passenger cars entering the rest area was nearly twice as maximum in the opposite direction). It can also be seen that the largest use of RA (the largest number of vehicles driving down to RA) occurs on Friday from 12:00 to 18:00. This period also coincides with the hours for which the greatest parking demand is observed (according to RA occupancy measurements conducted in 2017 in 9 car parks located along A4 motorway, in approximately $90 \%$ of cases, the maximum parking demand occurred between 12:00 and 16:00). Therefore, this period can be considered as meaningful for traffic analysis.

In order to complete the traffic characteristics, a relationship between vehicular volume on main road and entering RA was established (Figure 2). It shows, that the number of vehicles at the rest areas strongly depend on the number of vehicles on main road, especially in the case of RAs II and III categories (value of the coefficient $\mathrm{R}^{2}=0.90$ and 0.88 , respectively for Warsaw and Berlin direction). The obtained results coincide with the analyzes presented in [17].

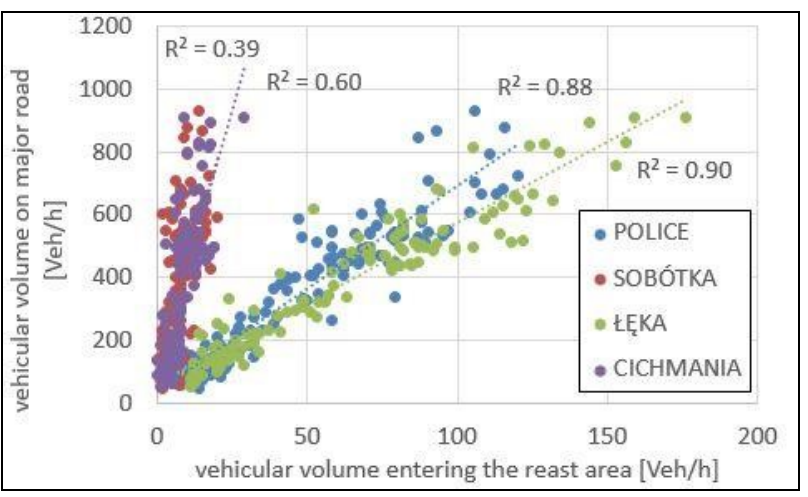

Fig. 2. Relationship between vehicular volume on main road and entering RA.

\section{Parking demand}

According to the results of previous analyzes [18], it was assumed that the number of spaces needed for passenger cars should be determined based on AADT (of light vehicles), the percentage of vehicles driving down to RA (value depends on spatial relationship and RA facilities) and the design hourly volume ratio (DH). In addition, seasonal variation of traffic volumes should be taken into account (transition from AADT to the average highest annual value by the SV index). The AADT (Annual Average Daily Traffic) was determined based on monthly and daily factors (roads of economic nature of traffic patterns $-\mathrm{DSRG}_{\mathrm{L}}$ - table 5, Figure 3) received from the cluster analysis, analogous to heavy vehicles presented in [19]. The analysis was performed based on data from continuous measurement stations of four types (Golden River, RPP-5, PAT and SICK) with respect to the directional daily light traffic volumes. The data was collected in years 2010-2015 from 30 stations located on motorways and expressways in different regions of Poland.

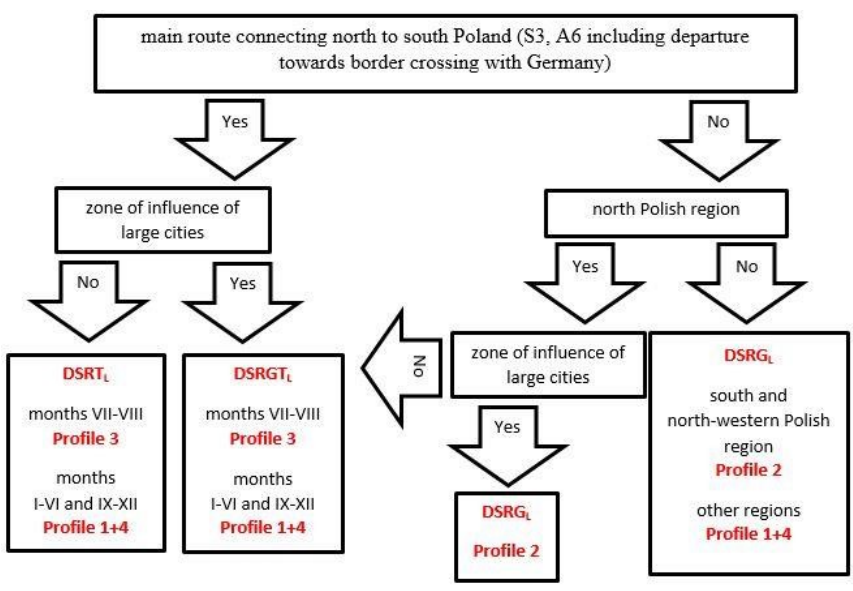

Fig. 3. Scheme of division of the road network into specific groups of light traffic volume variation (DSRGL - roads of economic nature of traffic patterns; DSRGTL - roads of economic-tourist nature of traffic; $\mathrm{DSRT}_{\mathrm{L}}$ - roads of tourist nature of traffic).

Table 5. The descriptive statistics for particular profiles (Seasonal variation - DSRGL, Weekly variation - Profile 1+4).

\begin{tabular}{|c|c|c|c|c|c|c|}
\hline & IX & Fri & Sat & Sun & Mon & Tues \\
\hline $\begin{array}{c}\text { aver. } \\
{[-]}\end{array}$ & 1.078 & 1.179 & 0.995 & 1.030 & 0.958 & 0.911 \\
\hline$\sigma[-]$ & 0.03 & 0.12 & 0.11 & 0.15 & 0.07 & 0.05 \\
\hline
\end{tabular}

The design hourly volume ratio (Friday between 12:00 - 18:00) was based on data from continuous measurement stations, equipped with the most modern counters - SICK. In total, data were gathered from 18 measuring sections from the year 2015. The result was the average yearly traffic share of hour 16:00 - 17:00 (the average highest annual value and the highest value in the months in which increased use of RA is observed, that is VII $-\mathrm{X}$ ), according to table 6 . As an alternative approach, often used in practice in other countries, the $\mathrm{DH}$ value was also determined as a share of the 50th peak hour in the year in AADT. For this purpose, it was necessary to determine the $\mathrm{u}_{50}$ value. The analyzes were carried out on the same database as in the case of monthly and daily factors. The obtained results are presented in Figure $4\left(\mathrm{DH}_{50}\right.$ value dependent on the AADT value). In the case of the roads of economic nature of traffic (DSRGL), due to the deviating characteristics for roads leading the traffic to and from the country borders, they were separated from analyzes and marked as: DSRGL* (average $\mathrm{u}_{50}$ value similar to the value obtained for roads of economic-tourist nature of traffic - DSRGTL). It should be noted that due to the limited number of continuous measurement stations within roads of tourist (DSRTL) and economic-tourist nature of traffic (6 stations in total), the presented values may not be typical for the whole country. In the future, 
as the database is expanded, the analysis should be continued.

Table 6. The share of traffic volume in a particular hour in daily traffic [\%].

\begin{tabular}{|c|c|c|c|c|c|c|}
\hline month & $\begin{array}{c}12: 00- \\
13: 00\end{array}$ & $\begin{array}{c}13: 00- \\
14: 00\end{array}$ & $\begin{array}{c}14: 00- \\
15: 00\end{array}$ & $\begin{array}{c}15: 00- \\
16: 00\end{array}$ & $\begin{array}{c}16: 00- \\
17: 00\end{array}$ & $\begin{array}{c}17: 00- \\
18: 00\end{array}$ \\
\hline I & 5.7 & 6.2 & 7.1 & 8.0 & 8.0 & 7.4 \\
\hline II & 5.6 & 6.2 & 6.9 & 7.7 & 8.0 & 7.4 \\
\hline III & 5.5 & 6.0 & 6.7 & 7.6 & 8.0 & 7.5 \\
\hline IV & 5.5 & 6.0 & 6.7 & 7.4 & 7.6 & 7.3 \\
\hline V & 5.3 & 5.9 & 6.5 & 7.3 & 7.5 & 7.3 \\
\hline VI & 5.4 & 5.9 & 6.5 & 7.1 & 7.4 & 7.1 \\
\hline \hline VII & 5.4 & 5.8 & 6.2 & 6.7 & 7.0 & 6.9 \\
\hline VIII & 5.5 & 5.8 & 6.1 & 6.8 & 7.0 & 6.9 \\
\hline IX & 5.5 & 5.9 & 6.4 & 7.1 & 7.6 & 7.4 \\
\hline X & 5.4 & 6.0 & 6.6 & 7.4 & 7.6 & 7.4 \\
\hline \hline Xverag & 5.5 & 6.1 & 6.9 & 7.7 & 7.9 & 7.5 \\
\hline \hline
\end{tabular}

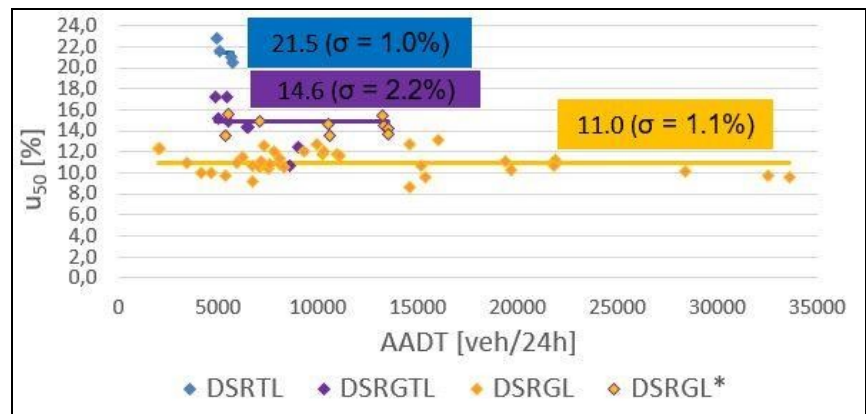

Fig. 4. Share of the 50th peak hour in the year in AADT

In order to verify the adopted approach, the maximum parking accumulation $\left(\mathrm{P}_{\mathrm{a}}\right)$ was determined, according to formula 1 . The results obtained are shown in table 7.

$$
P_{a}=A A D T \times S V \times P \times D H_{d}[\%]
$$

where:

AADT - Annual Average Daily Traffic in the analyzed direction of traffic,

SV - seasonal variation index (taking into account the peak month and day of the week in a year) having the value of 1.5 for roads with the economic nature of traffic patterns [18],

$\mathrm{P}$ - percentage of vehicles driving down to RA (because the number of needed parking spaces is expressed in the hour and not in the day, the value of $\mathrm{P}_{\max }$ was adopted, according to Table 4),

$\mathrm{DH}_{\mathrm{d}}-$ design hourly volume $\left(\mathrm{DH}_{16: 00-17: 00}=7.6 \%\right.$ or $\mathrm{DH}_{50 \mathrm{~h}}=11 \%$ - accumulation to volume ratio.

Analyzing the obtained results, it can be concluded that the adoption of hour 16:00 - 17:00 on Friday as meaningful (as the peak parking period) gives a better estimate of results than the adoption of the 50th peak hour of the year. Despite a slight increase or the lack of thereof in the estimated number of vehicles driving down to RA than actually observed in the measurements, the result, due to the share of vehicles driving down to RA that will not stop there, can be considered correct. In the current approach, it is assumed that approximately $20 \%$ of vehicles will not use parking spaces, which constitutes a reserve for potentially increased traffic during the summer. Adopting the 50th peak hour of the year results in a significant increase in the number of vehicles driving down to RA (on average by $48 \%$ ), which may lead to an overestimation of the number of needed parking spaces, which is economically unjustified.

Table 7. Parking demand determined through calculations and measurements.

\begin{tabular}{|c|c|c|c|c|}
\hline & & $\begin{array}{c}\text { computa } \\
\text { tional }\end{array}$ & $\begin{array}{c}\text { max from } \\
\text { measurements }\end{array}$ & $\begin{array}{c}\text { difference } \\
{[\%]}\end{array}$ \\
\hline \multirow{2}{*}{$\begin{array}{l}\text { RA III } \\
\text { Police }\end{array}$} & $\mathrm{DH}_{50 \mathrm{~h}}$ & 173 & \multirow{2}{*}{120} & 44.2 \\
\hline & $\begin{array}{c}\mathrm{DH}_{16: 00} \\
-17: 00\end{array}$ & 120 & & 0.0 \\
\hline \multirow{2}{*}{$\begin{array}{c}\text { RA I } \\
\text { Sobótka }\end{array}$} & $\mathrm{DH}_{50 \mathrm{~h}}$ & 29 & \multirow{2}{*}{20} & 45.0 \\
\hline & $\begin{array}{c}\mathrm{DH}_{16: 00} \\
-17: 00\end{array}$ & 20 & & 0.0 \\
\hline \multirow{2}{*}{$\begin{array}{l}\text { RA II } \\
\text { Łęka }\end{array}$} & $\mathrm{DH}_{50 \mathrm{~h}}$ & 269 & \multirow{2}{*}{176} & 52.8 \\
\hline & $\begin{array}{c}\mathrm{DH}_{16: 00} \\
-17: 00\end{array}$ & 186 & & 5.7 \\
\hline \multirow{2}{*}{$\begin{array}{c}\text { RA I } \\
\text { Cichmia } \\
\text { na }\end{array}$} & $\mathrm{DH}_{50 \mathrm{~h}}$ & 44 & \multirow{2}{*}{29} & 51.7 \\
\hline & $\begin{array}{c}\mathrm{DH}_{16: 00} \\
-17: 00\end{array}$ & 31 & & 6.9 \\
\hline
\end{tabular}

\section{Summary}

This study presented an investigation into rest area light traffic use and did so by analysis of 4 sites along motorway in central region of Poland. Analysis was performed based on data from each RA site collected for approximately one week (weekdays and weekend). The result of the analysis can be used by the road administration for predicting the parking demand on A2 motorway section out of influence of large metropolitan areas and border crossings. The general conclusions of this study are as follows: 
- Favourable distance between rest areas due to fatiguerelated crashes is from $15 \mathrm{~km}$ to $30 \mathrm{~km}$.

- Higher use of RA (the largest number of vehicles driving down to RA) occurs on Friday from 12:00 to 18:00. Thus this period can be used as meaningful for parking demand data collection in RA for light vehicles.

- There is a shift of the peak time of RA use in relation to the traffic peak in the main road. A good measure of the use of RA is the maximum number of vehicles entering the rest area divided by maximum main-line traffic (in an hour).

- The number of vehicles at the rest areas strongly depend on the number of vehicles on main road, especially in the case of RAs II and III categories.

- The use of RA depends on its individual facilities and direction of movement and varied from $2.1 \%$ to $19.3 \%$ of the main-line traffic entering the rest area.

- Adoption of hour 16:00 - 17:00 on Friday as meaningful (as the peak parking period) gives a better estimate of parking demand than the adoption of the 50th peak hour of the year (adopting the 50th peak hour of the year may lead to an overestimation of the number of needed parking spaces).

It should be noted that, due to the relatively small sample, the obtained results may be burdened with a certain amount of randomness, which is why the research should be continued. The author also recommends investigation of other variables that are thought to be important for the use of RA, such as location of RA (distance to big cities or border crossings) and trip purpose.

Research in frame of the project "Parking space in rest and service areas (RSA)" financed by NCBiR/GDDKiA as a part of common undertaking "RID", under the contract DZP/RID-I-44/8/NCBR/2016.

\section{References}

1. http://mib.gov.pl/files/0/1796809/RMUchwala1052 017.pdf (Uchwała nr 105/2017 Rady Ministrów z dnia 12 lipca 2017 r.)

2. K. Jamroz, L. Smolarek, Drogownictwo 4, 121-126 (2012)

3. A. Kupiec, J. Kupiec, Autobusy 12, 264-270 (2017)

4. I. Banerjee, J. Lee, K. Jang, S. Pande, D. Ragland, UC Berkeley Traffic Safety Center, California Department of Transportation (2009)

5. Evaluating the Appropriate Level of Service for Michigan Rest Areas and Welcome centers. Considering Safety and Economic Factors. Final Report ORBP Reference (2012)

6. https://www.bmvi.de/SharedDocs/DE/Artikel/StB/lk w-parken-in-einem-modernen-bedarfsgerechtenrastanlagensystem.html (2018)

7. J. Dierke, J. Kleine, R. Lehmann, Transportation Research Procedia 15, 620-627 (2016)

8. Forschung, Straßenbau und Straßenverkehrstechnik, 1126 (2017)
9. Bureau of Design and Environment Manua, Illinois Department of Transportation Division of Highway, Chapter sixteen (2017)

10. I. Ramli, S. Asmah Hassan, M. Rosli Hainin, Malaysian Journal of Civil Engineering 29 Special Issue (1), 108-118 (2017)

11. Guide for the Development of Rest Areas on Major Arterials and Freeways (AASHTO 2001)

12. http://prawo.sejm.gov.pl/isap.nsf/download.xsp/WD U20160000124/O/D20160124.pdf (Obwieszczenie Ministra Infrastruktury i Budownictwa $\mathrm{z}$ dnia 23 grudnia $2015 \mathrm{r}$.)

13. The strategic road network and the delivery of sustainable development, Department for Transport (2013)

14. S. Jung, S. Joo, C. Oh, Accident Analysis \& Prevention 99, Part A, 356-363 (2017)

15. A. Al-Kaisy, D. Veneziano, Z. Kirkemo, C. Dorrington, Transportation Research Record: Journal of the TRB 2303, 117-124 (2012)

16. A. Al-Kaisy, Z. Kirkemo, D. Veneziano, C. Dorrington, Transportation Research Record: Journal of the TRB 2255, 156-164 (2011)

17. I. Ramli, S. Asmah Hassan, M. Rosli Hainin, A. Minhans, Jurnal Teknologi 76:14, 9-21 (2015)

18. M. Spławińska, K. Solecka, Autobusy 12, 423-427 (2017)

19. M Spławińska, CMSAM2017, 190-194 (2017) 